\title{
不飽和土の非排水三軸圧縮試験における 変形強度特性および水分特性
}

\author{
河井克之 $^{1} \cdot$ 軽部大蔵 $^{2} \cdot$ 嘉戸善胤 $^{3} \cdot$ 加藤正司 $^{4}$ \\ ${ }^{1}$ 正会員 工博 神戸大学助手 工学部建設学科（T657-8501 神戸市樥区六甲台町 1-1） \\ ${ }^{2}$ フェロー会員 工博 侏セージ（テ541-0045 大阪市中央区道修町 4-5-22） \\ ${ }^{3}$ 正会員 工修 大阪府茨木土木事務所（广567-0032 大阪府茨木市西駅前町 5-10） \\ ${ }^{4}$ 正会員 工博 神戸大学助教授 工学部建設学科（T657-8501 神戸市鹳区六甲台町 1-1）
}

\begin{abstract}
不飽和供試体の非排水三軸圧縮試験を行い，不飽和土の非排水変形強度特性および水分特性について調べた. 試験は, まず飽和状態にある供試体を加圧板法で不飽和化し, その後供試体の間隙空気圧を一定に保ち, 非排水 状態で軸圧縮を行った. 比較的飽和度が高い供試体では, 間隙水圧は, せん断による体積圧縮とともに增加し, 膨張とともに消散した. しかしながら, せん断による体積嘭張量が曊著になってくると, 再び間隙水圧は增加し た. 一方, 飽和度が低い供試体では, 体積変化とは無関倸に, 間隙水圧が增加するという傾向が現れた. これは, バルク水とメニスカス水の骨格変形に対する作用の違いとして説明できることが分かった. また, サクション応 力を用いれば排水試験と同様の破壞基準を用いることができ, 飽和土の限界状態線と一致することがわかった.
\end{abstract}

Key Words: triaxial test, unsaturated soil, water distribution, undrained strength, dilatancy, water retention curve

\section{1.はじめに}

盛土や堰堤などの人工土構造物や, 自然斜面を構 成しているのは, 通常, 土間隙に空気相を含む不飽 和土である. 不飽和土塊内では，一般的に負の水圧 が生じているが, この負圧をどのように扱うかが問 題となった. Bishop"1，不飽和土の有効応力を次式 で表した.

$$
\sigma^{\prime}=\left(\sigma-u_{a}\right)+\chi\left(u_{a}-u_{w}\right)
$$

ここで, $\sigma^{\prime}$ は有効応力, $\sigma$ は全応力, $u_{a}$ は間隙空気 圧， $u_{w}$ は間隙水圧である． $\chi$ は飽和度に関するパラ メーターであり, 式(1)は, 基底応力(ネットストレ ス) $\sigma_{N}=\sigma-u_{a}$ とサクション $s=u_{a}-u_{w}$ の 2 つの応力 成分でもって挙動を表している.つまり Bishop らは, サクションが不飽和土の挙動に大きく影響を及ぼす ことを示した.

しかし，サクションは間隙水の形態によってその 作用が異なり, 有効応力理論にそのまま適用するこ とができない，サクションは, 飽和土における有効 応力のように骨格圧縮応力として作用するだけでな く, 圧縮による硬化とは別に土の剛性を高める作用 がある. 現在では，これらの作用を考慮した不飽和 土構成モテルがいくつか提案されており，それぞれ
パラメーターの選択により不飽和土の挙動を表すこ とができる.

ところで, これらの構成モテルは, 試験中のサク ションを制御する「排水試験」から導かれたもので あるが，サクションを制御しない「非排水試験」へ の適用に制限は付けられていない. 従って, 構成モ デルの検証方法の一つは非排水試験を行うことであ る. Bishop ${ }^{2)}$ は, 間隙空気圧と間隙水圧を測定し た非排気非排水三軸圧縮試験を行い, 不飽和土の挙 動に及ぼす応力成分を検討している. また, Satija ${ }^{3)}$ は, 供試体に作用させる空気圧を一定に保ち, 非排 水三軸圧縮試験を行い, 拘束圧によって間隙水圧の 変化に差が生じることを確かめている. しかし, 両 者とも不飽和土に作用する応力成分を定性的に検討 するに留まっている. 一方, Vanapalli ら ${ }^{4)}$ は非排水 強度に関して有効飽和度の導入により定量的な評価 をしているものの, 応力ひずみ関係については言及 していない.このように, 既存の構成モデルは非排 水試験によって定量的に検証されたことはない.

本研究では, 既存の水分特性曲線を考慮した構成 モテルを用いて外応力とサクションの相関関係を求 めることを目的としている. 試料には, 透水性の高 いシルト質粘土を用いて，不飽和土用三軸試験機で 不飽和供試体を, 種々の条件下で非排水せん断した. 


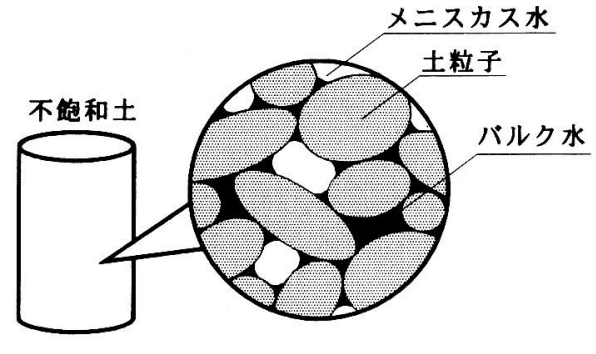

图-1 不飽和土中の間紧水の分類

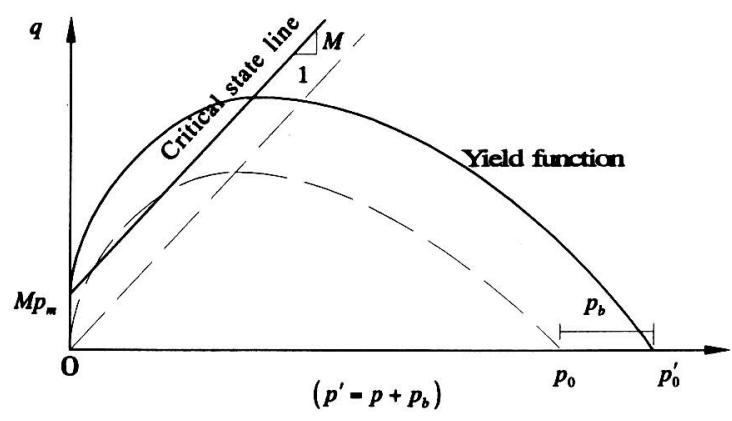

图-3 $p^{\prime} \sim q$ 平面での降伏関数

さらにこれまで行われた排水試験との比較から既 存の構成モテルへの適用性の検討を行った.

\section{2. 軽部らの不铇和土搆成モデル}

不飽和土は土中間隙に水と空気の相を持つ. その ため, 界面作用が生じ次式で表されるサクションが 生じる.

$$
s=u_{e}-u_{w}
$$

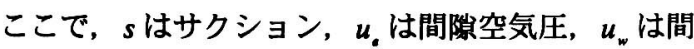
隙水圧を表す.サクションは不飽和士の挙動に大き く影響を及ぼすが，その隇少が土骨格の膨張だけで なくコラプスと呼ばれる圧縮挙動を引き起こす原因 となることから，サクションを変形と強度を統一的 に表す有効応力として定義することができない．こ のコラプス現象を表現し得る構成モデルがいくつか

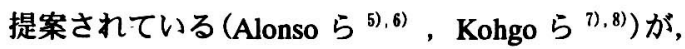
軽部らは土中の間隙水の構成割合から応力成分を算

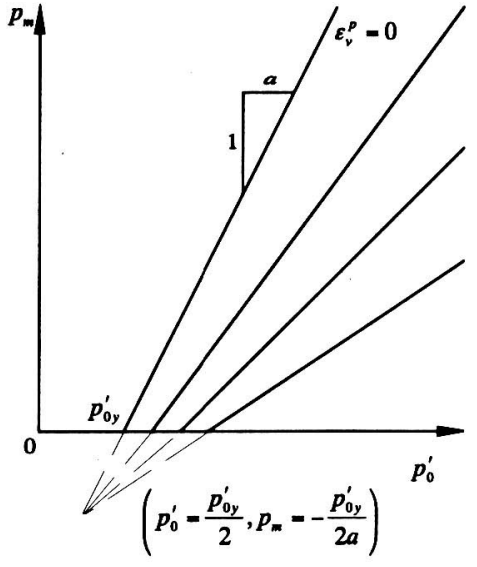

图-2 等方忍力面内での等塑性体積ひずみ線群

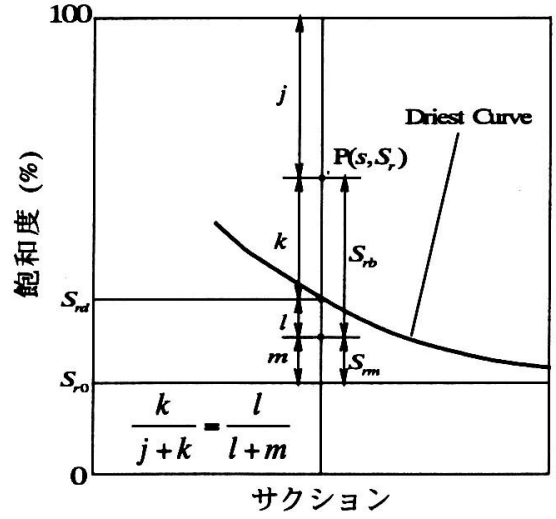

图-4 最乾燥水分線を用いた間隙水分布推定法

定し, モテルを構築することで, 飽和土の挙動を包 括する構成モテルを提案している.

軽部ら ${ }^{9), 10)}$ は，不飽和土中の間隙水を，バルク水 とメニスカス水に分類した. バルク水は图-1 中で示 すように土粒子間隙を占める間隙水，メニスカス水 は图-1 の土粒子接点に存在する間隙水である. 飽和 度が高いほどバルク水の占める割合が大きくなり, 飽和度の低下とともにメニスカス水の割合が增して くる. サクションは,この 2 つの間隙水の形態によ って作用が異なる. バルク水に作用するサクション は, 飽和土における負の間隙水圧と同等であって, 体積圧縮を引き起こすことを通じて土骨格の㓮性を 強める. 一方, メ二スカス水に作用するサクション は, 土粒子接点に対して垂直に侱くので, 体積圧縮 を伴わず剖性を強める. 不飽和土特有のコラプス現 象は, このメ二スカス水に作用するサクションが減 少し剛性が弱まるために起こると説明した.この 2 つの応力成分は，土骨格に対して等方的に作用し， それぞれバルク応力 $p_{b}$, メニスカス応力 $p_{m}$ と名付け られた。軽部らは,これらの応力成分を用いて不飽 
和土の等方圧縮挙動を次式で与えた.

$$
\frac{\partial e}{\partial p_{0}^{\prime}}=-\frac{\lambda}{p_{0}^{\prime}+a p_{m}}
$$

ここで, $e$ は間隙比, $p^{\prime}$ は骨格圧縮応力であり $p^{\prime}=p+p_{b}$ で表される. $p$ は平均基底応力であり $p=p_{T}-u_{a}$ で表される. $p_{T}$ は外応力として作用する 全応力表示の平均主応力. $\lambda$ は飽和状態での圧縮指 数. 添え字 0 は, 等方応力成分を意味する. 式 (3) は骨格圧縮応力 $p^{\prime}$ に対する土骨格の剛性が $\left(p^{\prime}+a p_{m}\right)$ に比例するという考えに基づく． $a$ は， メ 二スカス応力 $p_{m}$ の剛性への寄与率である. 弾塑性状 態では間隙比 $e$ は $p^{\prime}$ と $p_{m}$ の状態量であるとし, 初期 降伏関数を式 (4) で仮定し，Cam-Clay 理論を適用す ると体積ひずみ式(5)が得られる.

$$
\begin{gathered}
p_{0}^{\prime}=p_{y 0}^{\prime}+a p_{m} \\
\varepsilon_{v}{ }^{p}=\frac{\lambda-\kappa}{1+e_{i}} \log _{e} \frac{p_{0}^{\prime}+a p_{m}}{p_{y 0}^{\prime}+2 a p_{m}}
\end{gathered}
$$

ここで, $p_{y 0}^{\prime}$ は $p_{m}=0$ のときの $p_{0}^{\prime}, \kappa$ は飽和状態で の膨張指数, $\varepsilon_{v}{ }^{p}$ は塑性体積ひずみ, $e_{i}$ は基準点の間 隙比. 图-2 は式(5)で表される等塑性体積ひずみ線 群を表している.

軽部らはさらに三軸圧縮状態のエネルギー式を式 (6)で与え, 関連流動則を適用し式 (7)の降伏関数を 得た.

$$
\begin{aligned}
& q=M\left(p^{\prime}+p_{m}\right)-p^{\prime}\left(d \varepsilon_{v}{ }^{p} / d \varepsilon_{s}\right) \\
& \frac{q}{M}=-p^{\prime} \log _{e} \frac{p^{\prime}}{p_{0}^{\prime}}+p_{m}\left(1-\frac{p^{\prime}}{p_{0}^{\prime}}\right)
\end{aligned}
$$

ここで, $M$ は限界状態での応力比 $q /\left(p^{\prime}+p_{m}\right), \varepsilon_{s}$ は せん断ひずみ, $p_{0}^{\prime}$ は $q=0$ のときの $p^{\prime}$ を表す. 図-3 は式(7)を図示したものである.

これらの降伏関数を求めるためには, バルク応力 とメニスカス応力の定量的な評価が必要である. 軽 部ら ${ }^{11}$ は, 水分特性曲線を表すサクション〜飽和度 平面に最乾燥水分線を仮定し, 間隙水の構成割合を 示した (図-4). 最乾燥水分線は, バルク水の存在し ない最も乾嬠側の水分特性曲線であり, 高サクショ ン域では, 主吸水曲線(吸着水しか存在しない状態, 相当にサクションが大きな状態からの吸水曲線であ り, 吸水曲線の下限値) と一致する. 最乾燥水分線上 の飽和度 $S_{r d}$ を用いてバルク応力, メ二スカス応力を 次式で与えた.

$$
\begin{gathered}
p_{b}=\frac{S_{r b}}{100-S_{r 0}} \times s=\frac{S_{r}-S_{r d}}{100-S_{r d}} \times s \\
p_{m}=\frac{S_{r m}}{100-S_{r 0}} \times s=\frac{\left(100-S_{r}\right)\left(S_{r d}-S_{r 0}\right)}{\left(100-S_{r 0}\right)\left(100-S_{r d}\right)} \times s
\end{gathered}
$$

表-1 試料の物理的性質

\begin{tabular}{|c|c|c|c|c|}
\hline & $G s$ & $w_{L}(\%)$ & $w_{P}(\%)$ & $I_{P}$ \\
\hline No.5 クレ- & 2.70 & 43.0 & 29.6 & 13.4 \\
\hline
\end{tabular}

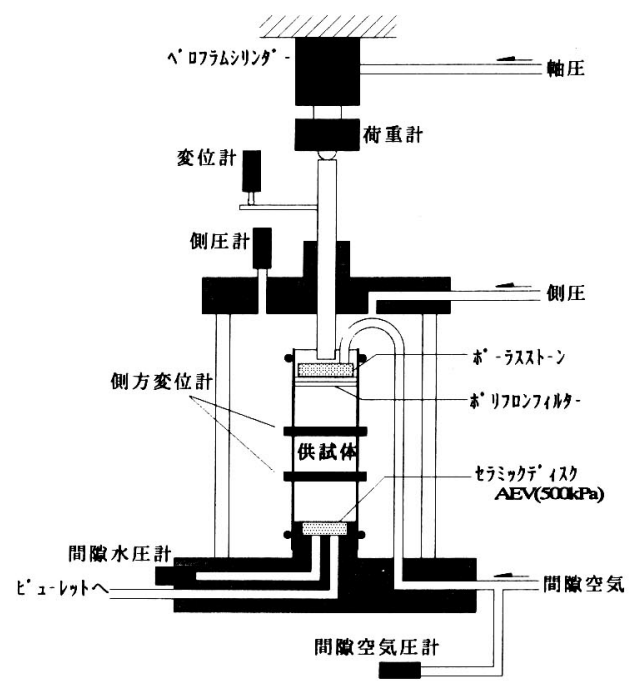

図-5 不飽和土用三軸試験機

ここで, $S_{r}$ は飽和度, $S_{r b}$ はバルク水の占める飽和度 分, $S_{r m}$ はメニスカス水の占める飽和度分, $S_{r 0}$ は残 留飽和度であり, 水分特性曲線の下限値を示す. ま た, 式(6)に見られるようにサクションの剛性を強め る作用はこの 2 つの応力成分の和で表され, サクシ ヨン応力 $p$, として次式で与えた.

$$
p_{s}=p_{b}+p_{m}=\frac{S_{r}-S_{r 0}}{100-S_{r 0}} \times s
$$

\section{3. 非排水三軸圧樎試験}

\section{（1）試料および試験装置}

試料には, 透水性の高い市販の No.5 クレーを用い た. その物理的性質を表-1 に示す．液性限界の 2 倍 の含水比に調整したスラリー状の No.5クレーを一次 元圧密容器 (直径 $100 \mathrm{~mm}$ ) に入れ, 段階載荷で 313.6kPa まで予圧密した. 予圧密ブロックサンプル を直径 $35 \mathrm{~mm}$, 高さ $80 \mathrm{~mm}$ に成形し, 不飽和土用三軸 試験機に設置した.なお, 試験時間は長期に及ぶた め, ゴムスリーブを介して供試体内の水が蒸発する のを防ぐために，2 重にしたゴムスリーブの間にシ リコングリースを塗布した.

試験装置には不飽和土試験用に改良された三軸試 験機を用いる. その概要を図-5に示す．本試験機内 では供試体上部より直接空気圧を作用させ, 供試体 下部のセラミックディスクを介して, 排水量または 
表-2 供試体に与えたサクション履歴と等方圧密終了時の供試体状態

\begin{tabular}{|c|c|c|c|c|c|c|c|}
\hline \multirow{2}{*}{ 供試体 } & \multirow{2}{*}{$\begin{array}{c}\text { サクション履歴 } \\
(\mathrm{kPa})\end{array}$} & \multicolumn{2}{|c|}{$\begin{array}{c}\text { 非排水圧縮段階での } \\
\text { 応力条件 }\end{array}$} & \multicolumn{2}{|c|}{ 非排水圧縮段階開始時の供試体状態 } & \multirow{2}{*}{$\begin{array}{c}\text { 試験時間 } \\
\text { (hour) }\end{array}$} \\
\cline { 3 - 7 } & & $p(\mathrm{kPa})$ & $u_{a}(\mathrm{kPa})$ & 間隙比 & 含水比 (\%) & 飽和度 $(\%)$ & \\
\hline I -1 & $0 \rightarrow 245$ & 245 & 245 & 0.959 & 28.8 & 81.2 & 188 \\
\hline I -2 & $0 \rightarrow 294 \rightarrow 48 \rightarrow 245$ & 245 & 245 & 0.919 & 23.1 & 67.8 & 538 \\
\hline I -3 & $0 \rightarrow 392 \rightarrow 48 \rightarrow 245$ & 245 & 245 & 0.950 & 19.7 & 55.9 & 694 \\
\hline I -4 & $0 \rightarrow 490 \rightarrow 245$ & 245 & 245 & 0.975 & 13.5 & 37.5 & 404 \\
\hline II -1 & $0 \rightarrow 245$ & 441 & 245 & 0.905 & 27.7 & 82.6 & 191 \\
\hline II -2 & $0 \rightarrow 490 \rightarrow 245$ & 441 & 245 & 0.920 & 13.9 & 40.9 & 550 \\
\hline III-1 & $0 \rightarrow 294$ & 245 & 294 & 0.923 & 21.0 & 61.6 & 180 \\
\hline III-2 & $0 \rightarrow 294$ & 441 & 294 & 0.881 & 20.6 & 63.2 & 215 \\
\hline
\end{tabular}

間隙水圧が測定できる.このとき, 排水状態であれ ば, 載荷空気圧がそのままサクションとなり, 非排 水状態であれば載荷空気圧と測定された間隙水圧の 差がサクションを示す.

\section{（2）試験方法}

試験はサクション載荷段階, 等方圧密段階, 非排 水軸圧縮せん断段階の 3 段階で行った.

サクション載荷段階では, 基底応力 $p=19.6(\mathrm{kPa})$ 下で予めスラリー状態から圧密された飽和供試体に 直接空気圧を作用させること (加圧法)により不飽和 化させた. このときに種々のサクション履歴を与え ることで, サクションと飽和度の組合せが異なる供 試体となるようにした. その後, サクションを一定 に保ち, 排水条件で等方圧密した (等方圧密段階). 非排水軸圧縮せん断段階では, 等方圧密された不飽 和供試体に作用している間隙空気圧を一定に保ち， ビューレットを閉じて, $p$ 一定せん断試験を行った. このときのサクションは載荷間隙空気圧と測定され た間隙水圧の差となる．表-2 に飽和供試体に加えら れたサクション履歴, 非排水軸圧縮せん断中の応力 条件および非排水軸圧縮せん断開始時の供試体状態 を示す．表中の I シリーズの 4 つの試験はせん断時 の応力条件 (拘束圧, 間隙空気圧) はすべて同じであ るが, せん断開始時の飽和度の異なる供試体である.

\section{4. 試臨結果および考察}

\section{（1）非排水せん断中の不的和土の体稘变化}

図-6 は, $p=245(\mathrm{kPa}), u_{a}=245(\mathrm{kPa})$ で非排水せん 断したときの, 応力〜ひずみ関係および間隙水圧の 変化である. 飽和度によって, 間隙水圧の発生の仕 方が異なるのがわかる. 飽和度が高い供試体(I-1)で は, 間隙水圧は, せん断初期の体積圧縮とともに増
加し，体積膨張とともに消散 0 している．これは飽 和土と同じ挙動である. しかし，せん断ひずみが進 行すると, 主応力差がピークを迎える辺りから, 体 積は膨張し続けているにも拘わらず，間隙水圧が再 び上昇傾向を示すようになる．供試体の飽和度が低 くなるにつれて, 間隙水圧の変化量も小さくなって いくが，いずれも体積最大圧縮点および主応力差が ピークとなる辺りで変曲点をもつことが確認できる. 図-7 は過去に同一試料で行った排水圧縮せん断試験 の結果であるが，同様の間隙水の吸排水挙動が見ら れている.この様な挙動は土塊内の間隙水分布の影 響を受けていると考えられる. 間隙がバルク水で占 められている土骨格では, 骨格の変形をバルク水が 受け持つため, 非排水試験では圧縮の際には間隙水 圧が増加し, 膨張の際には間隙水圧が消散する。 し かし，やがてこの土骨格の膨張が顕著になってくる と, 骨格に局部的な破壊が起こり, 大径のバルクが 形成される．そうすると，バルクに張っていたメニ スカスが破れて，一気にメニスカス水に転化する.

これに伴うメニスカス水の增加はサクションの隇少 につながり，間隙空気圧一定のもとでは結果的に間 隙水圧の上昇となって現れる.土全体としては，こ のバルク水とメニスカス水の挙動の和が現れるが, 間隙水圧の変化はバルク水量に支配されると考えら れる. つまり，飽和度が高くバルク水を多く含む供 試体ほど, 先述したバルク水の挙動が顕著に表れる と考えられる. なお，図-7(b)中， $\Delta$ 印の供試体につ いては, 口印の供試体よりも初期の飽和度が低く, よりメニスカス水の割合が多いと考えられる．その ため, 常に排水挙動を示すことについては説明可能 であるが，その量はロ印よりも大きい．この排水挙 動の一般性については現在検討中である.

図-7 の定サクション下での排水試験結果では, 飽 和度が高い供試体ほどせん断初期に体積が圧縮し， その後の膨張量も小さいという結果となった.これ は, 式(8) で示される拘束圧として作用するバルク応 

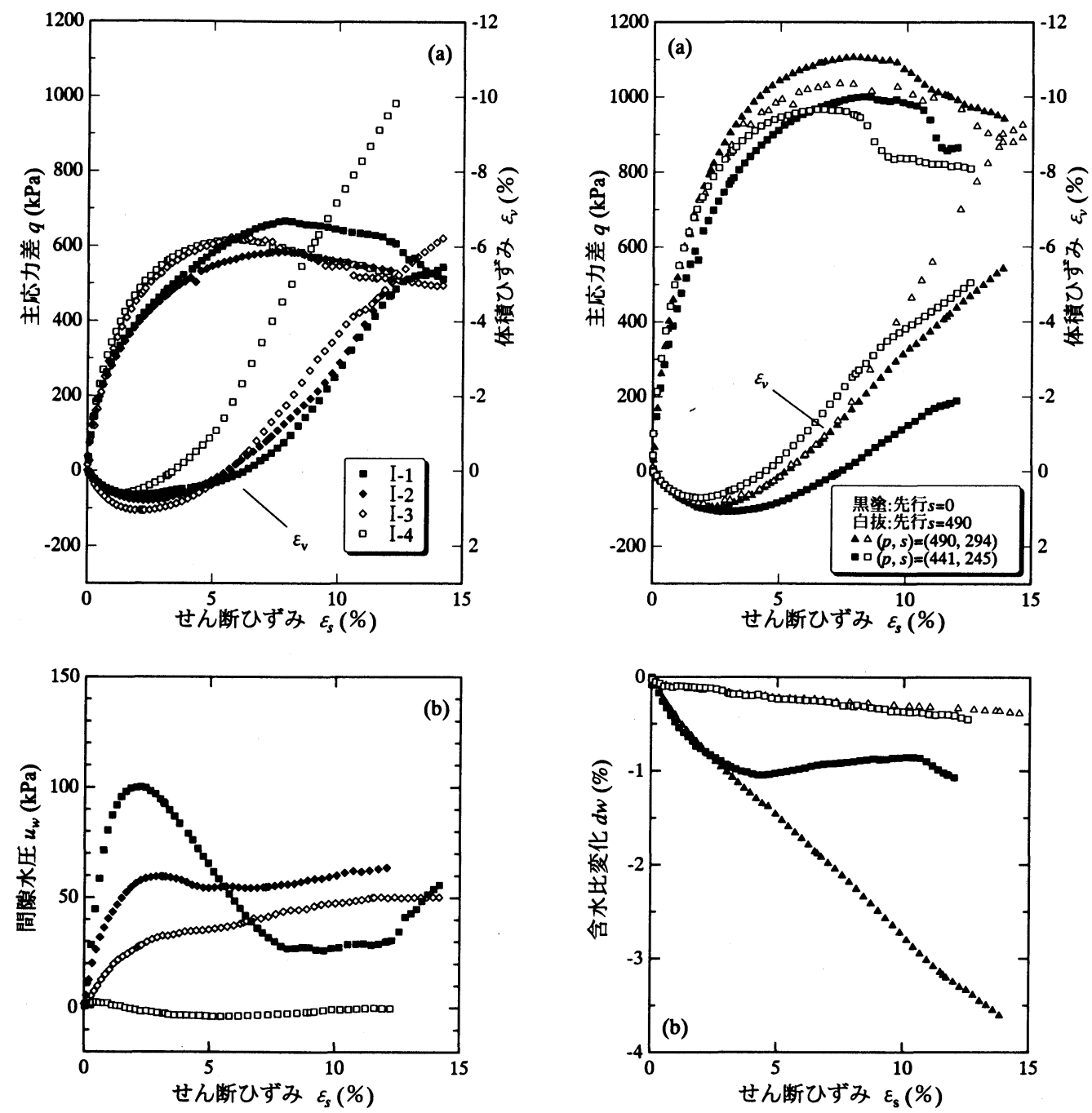

図-6Ｉシリーズの応力〜ひずみ関係 およひ間隙水圧変化

力が, 飽和度とサクションの関数となっていること から説明できる. 同じサクション值でも飽和度が高 いほどバルク応力が大きくなり, 拘束圧が発揮され るという理論に一致する. 一方, 非排水試験では, I -1 $\rightarrow$ I - $2 \rightarrow I-3$ と飽和度が低くなっているにも拘 わらず圧縮量が増加している。これは, 飽和度の高 い供試体ほど, せん断中にサクションが減少し結果 として式(8)のバルク応力が小さくなるからである. しかし, 膨張量に関しては飽和度の低い供試体ほど 大きくなり, 従来の試験結果に一致し, 式(8) を満た さない. 先述したように, せん断が進み体積膨張が 始まると, バルク水がその形状を保てず, バルク応 力が発揮できなくなり，メニスカス応力によって骨 格を保持 (土粒子のバルクへの落ち込みを防止)しょ うとする作用が卓越してくると考えられる.メニス

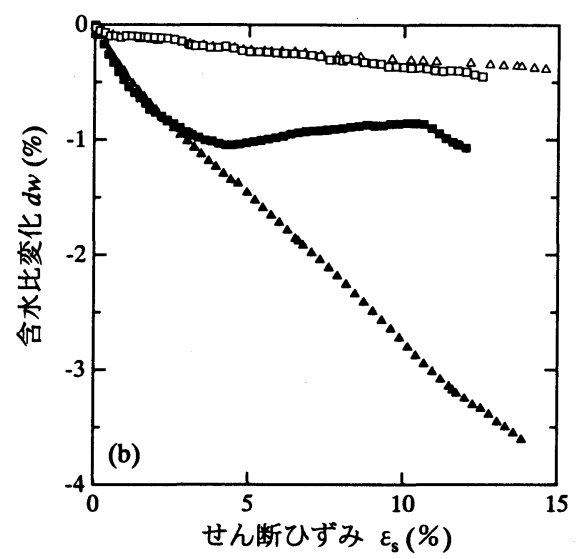

図-7 同一試料で行われた排水試験結果 ${ }^{12)}$

カス応力は, メニスカス水の割合が同じであれば, サクション値に依存するので, せん断による間隙水 圧の変化が小さい, つまり飽和度の低い供試体ほど 非排水せん断時に剛性が保たれると説明できる.

\section{（2）非排水せん断中の水分特性曲線変化}

前節において, せん断中の間隙水圧と体積変化挙 動を説明したが, 間隙空気圧一定で間隙水圧が増加 するということは式(2)でのサクション減少を, 非排 水状態での体積圧縮は飽和度の増大を意味する. つ まり, 供試体は水分特性曲線でいう, 脱水曲線 (サク ション增加による飽和度の隇少) および吸水曲線 (サ クション減少による飽和度の增加）上を動くことに なる. 図-8 はせん断試験中の水分特性曲線である. 図中には河井ら ${ }^{13)}$ が提案している水分特性曲線モデ 


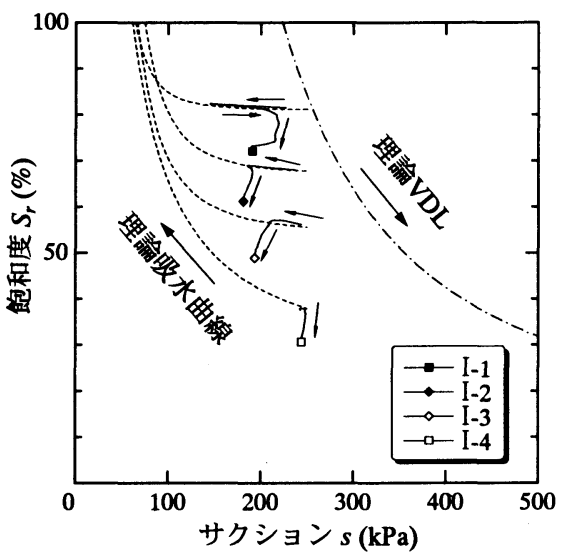

图-8 非排水圧縮段階での水分特性曲線

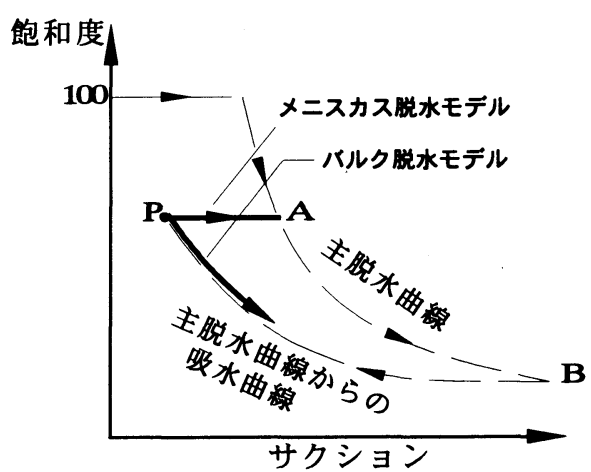

図-9 河井の水分特性曲線モデル
ルを用いて理論脱水曲線および吸水曲線が描かれて いる. この理論曲線は外力を一定に保った状態でサ クションだけを独立に変化させた場合を示している. 図中の「理論 VDL」は, 飽和試料にサクションを作用 させたときに得られる脱水曲線 (主脱水曲線) である. 実線で示した実測曲線は初期の体積圧縮段階では理 論吸水曲線に一致し, 体積が膨張に転じても当初は 吸水曲線に沿うような脱水曲線を示している.

不飽和状態にある土の脱水曲線の挙動は明らかに はされていない. 河井 ${ }^{14)}$ は, 任意の不飽和状態が主 脱水曲線からの吸水曲線上にあると考え (図-9), 次 のような脱水曲線モテルを提案している. 現在の含 水状態 (点 P) は過去により高いサクション值 (点 B) を経験しているのと同様に考えることができる. 主 脱水曲線は, 土中の大きな間隙から順にバルク水膜 が破られ，バルク水を排出していく過程である. 吸 水過程ではバルク水が排出された間隙を形成する骨 格のメニスカス水のメニスカスの曲率半径が大きく なり, 隣りのメニスカスと接触してバルク水となっ ていくが，インクビン効果(途中で径の異なる間隙が 連続している場合, 毛管圧が, 排水過程では最小の 径に, 吸水過程では最大の径に依存すること)および メニスカスの進行方向による曲率の違いが生じるた め, 同じ飽和度まで回復するのは脱水過程より低い サクション值である. これが現在の含水状態 (点 $\mathrm{P}$ ) であるとすると, 再脱水過程では 2 通りの考え方が できる. ひとつは, サクションが増加するときに, 再びバルク水膜を破るためには, 過去に受けた同じ サクション值 (点 A)に達しない限り, バルク水の排 出は起こり得ないとする考え方である. 点 $\mathrm{P}$ から点 A まで, メニスカス水の膨張・収縮はあるものの飽 和度に大きく影響するバルク水の変化が少ないと考 えると, 主脱水曲線に達するまでは飽和度は変化し
ないとしてモデル化することができる.もう一方は, 吸水過程でバルク水が回復していく速度と再脱水過 程でバルク水が減少していく速度が等しいとする考 え方であり, 主脱水曲線に達する(点 B) までは吸水 曲線と再脱水曲線が一致する.この考方方は, Tol1 ${ }^{15)}$ の再脱水曲線を定量的に表現したものである.この 2 つの概念に基づくモテルを，前者をメニスカス脱 水モテル, 後者をバルク脱水モデルと呼んでいる. 河井は数本のデータではあるが, バルク脱水モテル の方が実際の挙動によく一致するとしている ${ }^{14)}$. 図 -8におけるサクションの増加過程は, このバルク脱 水モデルに相当する. しかしながら, せん断中の供 試体の膨張が顕著になってくると, サクション変化 による理論水分特性曲線から冕脱していく．この現 象は不飽和土中の応力成分のひとつ, バルク応力に よって説明することができる. 図-10 は Karube ら ${ }^{16)}$ によって次式で具現化された最乾嬠水分線とそのと きのバルク応力分布である.

$$
\begin{aligned}
& s \geq s_{A}: \quad S_{e}=\frac{s_{r d}-S_{r 0}}{100-S_{r 0}}=\left(\frac{s_{W}}{s}\right)^{\alpha} \\
& s \leq s_{A}: \\
& \quad S_{e}=\left(\frac{s_{W}}{s_{A}}\right)^{\alpha}\left\{-(\alpha+1)\left(\frac{s}{s_{A}}\right)^{2}+(\alpha+2)\left(\frac{s}{s_{A}}\right)\right\}
\end{aligned}
$$

ここで $s_{A}, s_{W}$ はそれぞれ水分特性曲線の脱水曲線,吸 水曲線に現れる変曲点であり空気侵入値,水侵入値 である. $\alpha$ は実測の吸水曲線を Brooks and Corey 式 17で近似したときに現れる曲率を表す形状パラメー ターである. この最乾燥水分線式は実際の吸水曲線 のパラメーターを用いて，最も飽和度が低い状態で 描く吸水曲線式として表現しているため, 実測の吸 水曲線と交わることがないという点で合理的である といえる．図中には図-8 で表した供試体を含むすべ 


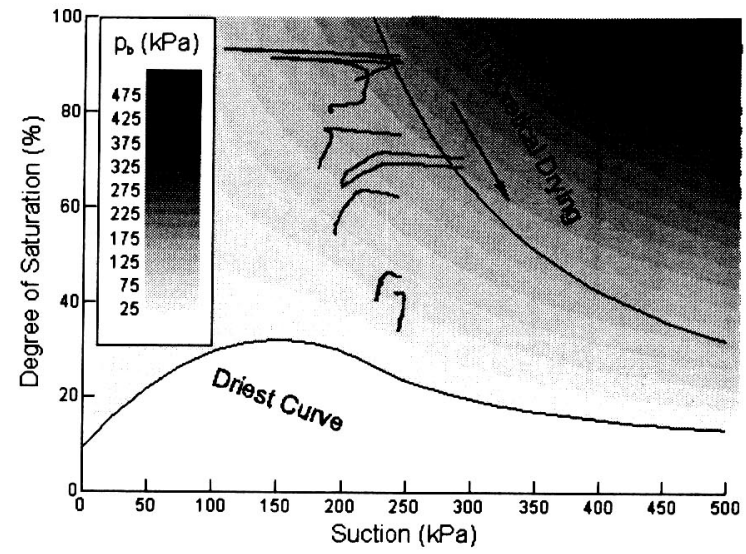

图-10 最乾嬠水分線とバルク応力分布

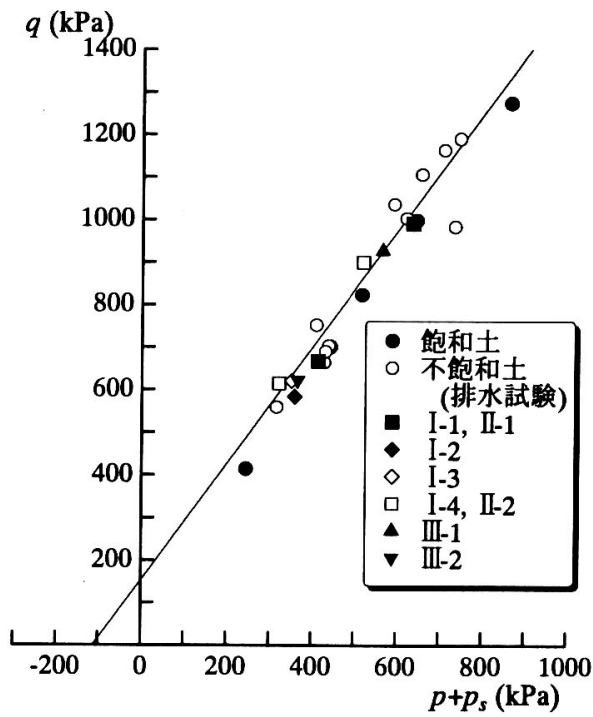

図-12 主応力差ピーク時の応力状態

ての供試体の水分特性変化をあわせて示しており, 濃淡によってバルク応力の大小を表現している．図 よりせん断によって体積が圧縮していく場合, サク ションの減少とともにバルク応力が減っていき, 体 積の膨張段階ではサクション増加によりバルク応力 が増加しているのが分かる. 図-11 は, せん断中の バルク応力と飽和度の関係である. せん断による膨 張につれて, 状態径路は破線まで水平に動き，その 後, 破線に沿って推移する.これは, 飽和度によっ て間隙水のキャビテーションが生じるサクション值 が決まっており，飽和度が高い場合は間隙水の量が 多いため単位面積での抵抗サクションが大きくなる ということを意味している. 図中では飽和度と限界 のバルク応力の関係が線形関係にあるとして，その 限界線を破線で描いている. このように, バルク応

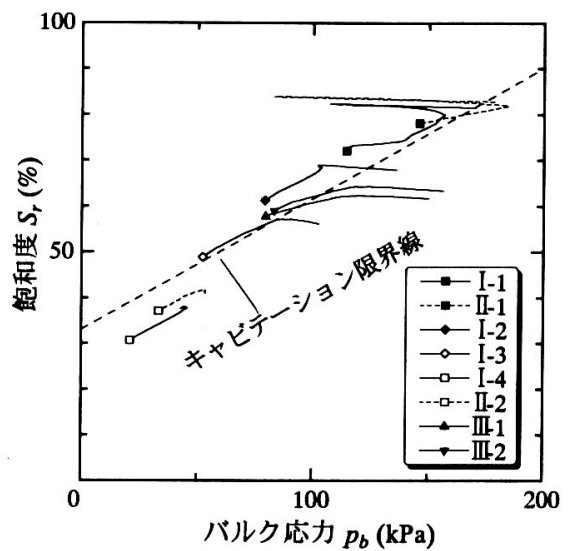

図-11 膨張がバルク応力 $p_{b}$ に及ぼす影数

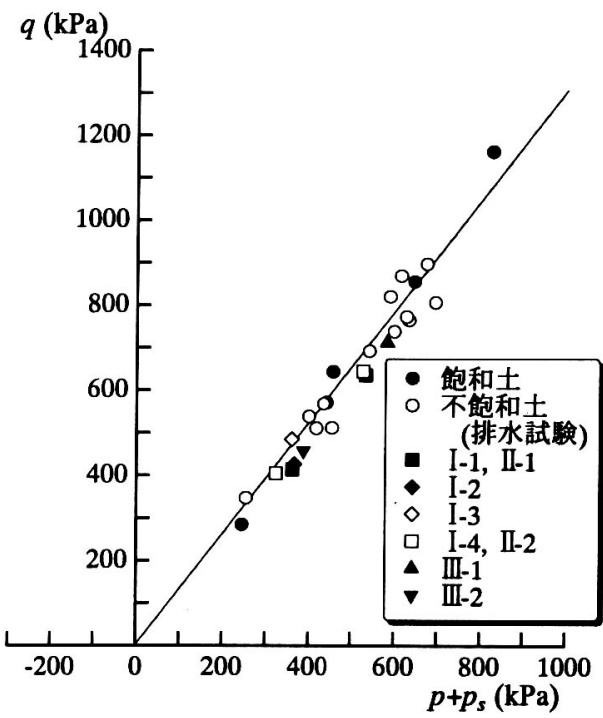

図-13 体積最大圧縮時の応力状態

カの上限となる線が設定できれば, サクションの変 化を予測することができる. ただし，供試体 I -4, II -2 のように飽和度が小さくバルク水の割合が小さい 場合は, サクションの変化は小さく応力成分の変化 はせん断時の体積変化による飽和度の変化にのみ依 存し, 結果として図-11 のような挙動となる.

\section{（3）非排水せん断強度}

図-12 は, 破壊時の応力状態をサクション応力 $p_{s}$ (式(10))で整理したものである. $p_{s}$ の算定には実 測の水分特性曲線より得られた $S_{r 0}=9(\%)$ を用いた. 図中には排水条件で得られた既存の飽和・不飽和土 の三軸試験結果も丸印で記している.これまでわか っているように, 破壊時のダイレイタンシー量は飽 和度に依存し，ダイレイタンシーの影響を含んだせ 


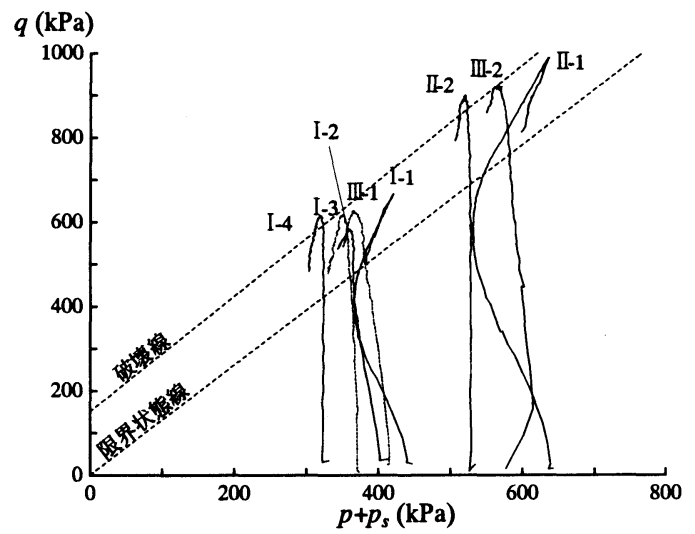

图-14 せん断中の応力径路

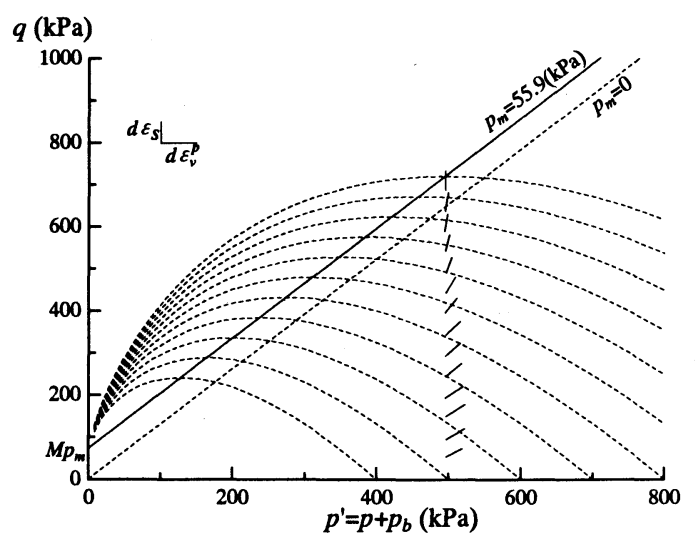

図-15 実測ひずみ増分方向と理論降伏線

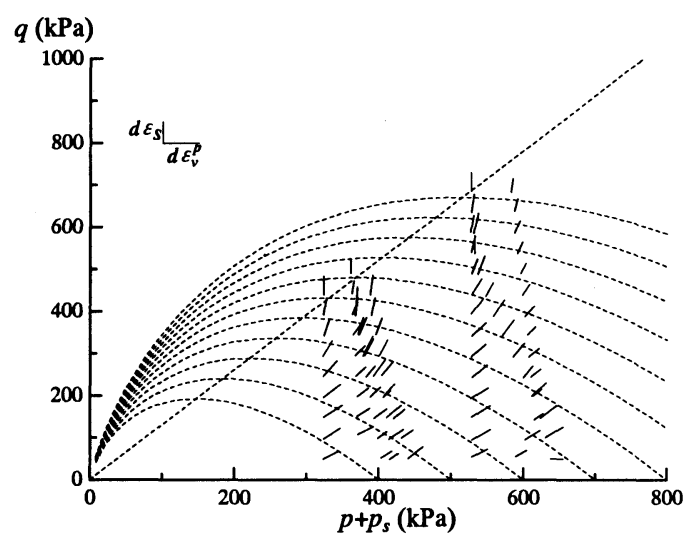

图-16 全供試体のひずみ増分方向と近似降伏線

ん断抵抗力からは限界状態を推定することはできな い. 限界状態の応力状態を正確に評価するには, ダ イレイタンシー補正を行う必要があるが，ダイレイ タンシーを規定するバルク応力の算定方法はまだ確 立していない. そこで, ダイレイタンシーの影響が 含まれない体積最大圧縮点で応力状態を表すと, 図 -13 が得られる. 図より今回の非排水試験結果は,
既存の排水試験の結果とよく一致することが分かる.

\section{（4）非排水せん断中の応力ひずみ関係}

図-14 は試験中の応力径路である. 飽和土におい ては, 非排水試験の描く応力パスは応力面上での等 間隙比線を表すが, 不飽和土では間隙空気の体積変 化が許容される. 非排水せん断は, $p$ 一定で行われ たので, サクション応力 $p_{s}$ (式(10)) が変化しなけれ ば, $q$ 軸に平行な直線となる. 飽和度が高い供試体 ( I -1, I -2, I -3) は, 主としてサクションの変動の ために飽和砂に似た径路を示した. その他の供試体 は, 主としてピーク後の激しい体積膨張による飽和 度の減少を反映して, 径路が左下がりとなった.

つぎに, 図-15 は式 (7)で与えられる理論降伏線 (破 線)上に実測ひずみ増分方向 (実線)を記入したもの である. 理論線は, 両者が直交すると仮定して求め られたが, せん断が進めば実際に直交状態が認めら れる. ただし,ここではせん断中に $p_{m}$ の変化が最も 小さい供試体 II -2 について検討を行っている.

$p_{m}$ の異なる全供試体の直交状況を検討するため に, 図-16では $p_{m}=0$ と仮定し, 横軸を $\left(p+p_{s}\right)$ とし て図を描いた．実際には $p_{m}=0$ ではなく，それぞれ の供試体において異なる降伏面を持ち, せん断試験 中にも $p_{m}$ の值が変わるため降伏関数の相似中心も 変化するが, この応力面内では応力状態に比べて $p_{m}$ は十分に小さいため, $p_{m}=0$ と仮定した降伏線との 比較を行っても差し支えない。結果的に，せん断初 期には供試体作製時の一次元圧密および弾性ひずみ の影響でいくらか角度を持っているが，せん断の進 行とともに降伏線とひずみ増分べクトルは直交して いるのが確認でき, 関連流れ則の妥当性とともに降 伏面が相似的に拡大するのが分かる. また, 試験 I -1 や吕-1 は，せん断中に拘束圧を表す $p+p_{b}$ が大き く変化しているにも拘らず, 同じ応力状態なら他の 供試体と同じひずみ増分ベクトルを有しており，応 力径路への依存性は見られない.

\section{5. 結論}

不飽和土の非排水条件下での変形強度特性および 外応力とサクションの関係について調べた．以下に 本研究より得られた結論をまとめる.

（1）不飽和土中の間隙水は, 土全体の体積変化によ つて複雑な挙動を呈する. 間隙水圧変化はバル ク水の割合に支配され, 体積圧縮とともに間隙 水圧が增加, 体積膨張とともに間隙水圧が消散 する. しかし, せん断変形による膨張量が卓越 
してくると, 膨張を拘束していたバルク水膜が 壊れてしまい，再び間隙水圧が漸増する.

（2）不飽和土の非排水せん断試験での体積変化は, 排水試験によるものと定量的に異なる. せん断 初期の体積圧縮段階では, バルク応力による拘 束圧の効果が発揮される. 同じサクション值で あれば飽和度が高いほどバルク応力が大きくな り, 圧縮量も增加する. しかし, 非排水試験に おいては飽和度の高い供試体において, 圧縮に よる間隙水圧がより大きく上昇しサクションが 減少するため, バルク応力が発揮されず, 圧縮 量も小さくなった. しかし, 膨張に関してはこ のバルク応力とは無関係に, 既存の排水試験同 様に, 飽和度の低い供試体ほど膨張量が大きく なった.

（3）せん断強度に関しては, サクション応力を適用 し，体積最大圧縮点を限界状態として考えると， 排水試験と非排水試験で同じ限界状態線を設定 できることが分かった。この限界状態線は，飽 和土のせん断試験から得られる限界状態線と同 じである.

（4）これまで, 不飽和土におけるエネルギー式に関連 流れ則を適用して降伏関数を求めていた. 今回, 応力空間に実測されたひずみ増分ベクトルを示 した. その結果, 降伏関数とひずみ増分べクト ルの直交性が確認された.

\section{参考文献}

1) Bishop, A.W. : The principal of effective stress, Norwegian Geotechnical Institute 32, pp.1-5, 1960.

2) Bishop, A. W., Alpan, I., Blight, G. E. and Donald, I. B. : Factors controlling the shear strength of partly saturated soils, in ASCE Res. Conf. Shear Strength of Cohesive Soils, pp.503-532, 1960.

3) Satija, B. S. : Shear behavior of partly saturated soils, Ph.D. dissertation, Indian Inst. Of Technol., Delhi, 327pp., 1978.

4) Vanapalli, S. K., Fredlund, D. G., Pufahl, M. D. and Crifton, A. W. : Model for prediction of shear strength with respect to soil suction, Canadian Geotechnical Journal, Vol.33, No.3, pp.379-392, 1996.
5) Alonso, E.E., Gens, A. and Hight, D.W. : Special problem soils, General Report, Proc 9th Europian RC-SMFE, pp.1087-1146, 1987

6) Alonso, E.E., Gens, A. and Josa, A. : A constitutive model for partially saturated soils, Geotechnique 40, pp.405-430, 1990.

7) Kohgo, Y., Nakano, M. and Miyazaki, T. : Theoretical aspects of constituitive modeling for unsaturated soils, Soils and Foundations, Vol.33, No.4, pp.49-63, 1993.

8) Kohgo, Y., Nakano, M. and Miyazaki, T. : Verification of the generalized elasto-plastic model for unsaturated soils, Soils and Foundations, Vol.33, No.4, pp.64-73, 1993.

9）軽部大蔵, 勝山潤一, 西海健二, 丹羽尚人：不飽和 土の三軸圧縮状態における降伏関数, 土木学会論文集, No. 406/III-11, pp. 205-211, 1989.

10）軽部大蔵：ビショップの有効応力を含む不飽和土の 応力・ひずみ式, 「土質工学会 三軸試験方法に関す るシンポジウム」発表論文集, pp. 137-144, 1991.

11）軽部大蔵, 加藤正司, 浜田耕一, 本田道識 : 不飽和 土の間隙水状態と土塊の力学的挙動の関係について, 土木学会論文集, No. 535/III-34, pp. 83-92, 1996.

12）河井克之, 本田道識, 藤原照幸, 軽部大藏：不飽和 土の三軸圧縮強度に及ぼす間隙水分布の影響, 土木学 会関西支部年次学術講演会, III-45, 1994.

13）河井克之, 軽部大蔵, 芦田渉, 嘉戸善胤：間隙比を 考虑した水分特性曲線モデル，土木学会論文集， No. 666/III-53, pp. 291-302, 2000.

14）河井克之：水分特性曲線のモデル化および不飽和土 における土骨格と土中水の連成問題, 神戸大学学位論 文, 2000 .

15) Toll, G.D. : A conceptual model for the drying and wetting of soil, Proc 1st Int Conf on Unsaturated Soils 2, 805-810, 1995.

16) Karube, D., Kato, S., Honda, M. and Kawai, K. : A constitutive model for unsaturated soil evaluating effects of soil moisture distribution, Proc 2nd International Conference on Unsaturated Soils, pp.485-490, 1998.

17) Brooks, R.H. and Corey, A.T. : Properties of porous me-dia affecting fluid flow, Proc ASCE 92 IR(92), pp.61-88, 1966

(2001.11.9 受付) 


\section{THE MECHANICAL BEHAVIOR OF UNSATURATED SOILS AND WATER RETENTION CHARACTERISTICS ON UNDRAINED TRIAXIAL COMPRESSION TEST}

\section{Katsuyuki KAWAI, Daizo KARUBE, Yoshitane KADO and Shoji KATO}

A series of triaxial compression tests is carried out on the unsaturated silty kaolin clays. Specimens are subjected to undrained compressive shear under the conditions of constant air pressure. The pore water pressure and volume change during shear are monitored. The pore water pressure develops with compression and then turns to decrease with expansion when the degree of saturation is relatively high. On the contrary to it, when the degree of saturation is low, the pore water pressure monotonically increases independent of volume change. These experimental facts can be explained from the effects of the bulk stress. Thus, throughout experimental investigations, it is revealed that the behaviors of unsaturated soils are consistently explained in terms of the meniscus and the bulk stresses. Particularly, it is found that the failure criterion on unsaturated soils can be uniquely described using the suction stress, which is defined as the summation of meniscus and bulk stresses. 